\title{
A National Army Under the Red Banner? The Mobilisation of the Hungarian Red Army in 1919
}

\author{
Tamás Révész (D) \\ ELRN Centre for Humanities, Institute of History, Tóth Kálmán u. 4, Budapest H-1097, Hungary \\ revesz.tamas@abtk.hu
}

This paper investigates the mobilisation of the Hungarian Red Army in 1919 by the short-lived Hungarian Soviet Republic. It challenges the literature's existing interpretations, explaining the successful mobilisation of the regime with its 'nationalist' or 'Bolshevik' character. First, the paper examines the military policy of the regime, arguing that it was not a mere copy of the Russian communist model but was a unique combination of social-democratic and communist ideas. Second, it analyses the recruitment propaganda and demonstrates how it combined dogmatic Bolshevism with traditional elements of the wartime propaganda. Third, it investigates the methods used by the Hungarian Soviet Republic to mobilise the population both in Budapest and in the rural eastern countryside. It argues that the mobilisation was possible through the involvement of civil associations (mostly the trade unions) and the incorporation of the former Habsburg regiments in the new Red Army.

In late June 1946, the People's Court in Budapest sentenced Colonel General Ferenc Szombathelyi to life imprisonment. He was one of the most prominent military experts of the interwar Horthy regime and the chief of staff of the Hungarian Army between 1941 and 1944. Only a few months later, he was extradited to Yugoslavia, where he was executed for his alleged role in the Novi Sad massacre. ${ }^{1}$ The politician who signed his extradition was István Ries, the social democratic Minister of Justice. Probably only a handful of people knew at that time that only twenty-seven years earlier these two men had served together in the army of the second Bolshevik state of Europe, the Hungarian Republic of Councils. While Ries, a committed socialist, had supported the regime from the outset, Szombathelyi, like many other former Habsburg officers, had joined the Bolshevik armed forces during late April 1919.

Largely thanks to the efforts of these officers, the Red Army, which numbered almost 200,000 men, led a temporarily successful campaign against the Czechoslovak forces and managed to occupy large territories of today's eastern Slovakia. The massive support for the communist regime only began to fade in the summer of 1919. The Soviet state finally collapsed after Romanian troops captured Budapest in early August. Since then, the temporary but undoubtedly spectacular success of the Hungarian Soviet Republic has become a debated topic in the historiography.

Over the course of the past century, two main interpretations were developed in the secondary literature. First, the mobilisation was portrayed as a product of 'covert nationalism'. It was claimed that, despite the Bolshevik nature of the regime, people joined the armed forces to defend their country or, more precisely, the borders of 'Greater Hungary'. This narrative has two distinct origins. First, Western European diplomats delegated to Budapest argued that the dogmatic leftist ideology of the Bolshevik regime only aimed to obscure its real goal, which allegedly was the restoration of the pre-war state

\footnotetext{
1 See his biography: Lóránd Dombrády, Szombathelyi Ferenc vezérezredes (Budapest: HM HIM, 2012).

(c) The Author(s), 2021. Published by Cambridge University Press. This is an Open Access article, distributed under the terms of the Creative Commons Attribution-NonCommercial-NoDerivatives licence (http://creativecommons.org/licenses/by-nc-nd/4.0/), which permits noncommercial re-use, distribution, and reproduction in any medium, provided the original work is unaltered and is properly cited. The written permission of Cambridge University Press must be obtained for commercial re-use or in order to create a derivative work.
} 
borders. ${ }^{2}$ Second, many members of the interwar Hungarian military elite, including Ferenc Szombathelyi, had served in the Red Army. As they later came to serve prominent roles under an ideologically very different regime, they sought to legitimise the roles they had played under the Bolsheviks. Consequently, they argued that, as officers, they had only fought for 'national' aims. ${ }^{3}$ A major alternative narrative was propagated by post-1948 socialist historiography. They argued that the effective mobilisation showed that large parts of the population supported the Bolshevik cause. They also often contrasted the success of the Soviet regime with the inability of the liberal-social democratic Károlyi government to organise a powerful military force. ${ }^{4}$

Meanwhile, since the late 1960s, scholars have published more balanced histories of the Soviet regime, which combine the narratives of the nationalist and Bolshevik schools. ${ }^{5}$ Historians working on both sides of the Iron Curtain also began to concentrate on the post-1918 transition. ${ }^{6}$ These studies mostly did not focus on the military history of the period but rather highlighted the role of the social democrats in the effective mobilisation. ${ }^{7}$ Since the late 1980s, interest in the Soviet Republic has decreased rapidly, and the Treaty of Trianon became the central theme of the historiography. ${ }^{8}$

Meanwhile, after 1990, international scholarship began to investigate the nature of military mobilisation in modern conflicts. Scholars like John Horne defined total mobilisation in the First World War as a complex cultural and political process, which evolved within limits. Horne defined two separate waves of mobilisation. The first wave began in 1914, and it was characterised by the self-mobilisation of society, while the second, which took place in 1917-18, was conducted by the state bureaucracies. ${ }^{9}$ Meanwhile, other scholars began to challenge the concept of war enthusiasm as characteristic of the summer of 1914. They argued that people's reactions could be more accurately portrayed as a mixture of fear, confusion and resignation. ${ }^{10}$ New studies also have been published about the phenomenon of volunteering to serve in the war. The authors of these texts argue that, alongside patriotism, other factors like peer pressure and the perception of an imminent threat also motivated people to enlist. ${ }^{11}$ New volumes have examined the Bolshevik revolutionary mobilisation as well. For example, Joshua Sanborn argues persuasively that it was not simply communist ideology and repressive methods that led to the establishment of an effective Russian Red Army, but also the well-established local recruiting offices and the creation of a new unifying discourse. ${ }^{12}$

2 Miklós Lojkó, British Policy on Hungary, 1918-1919: A Documentary Sourcebook (London: 1995), 120, 312

3 Ferenc Julier, 'Ellenforradalmi lélekkel a Vörös Hadsereg élén', Hadtudomány, 3 (1993), 2, 102-7.

4 Ervin Liptai, Vöröskatonák Elöre! (Budapest: Zrínyi Kiadó, 1979). About the post-1945 myth of the Soviet Republic see: Péter Apor, Fabricating Authenticity in Soviet Hungary: The Afterlife of the First Hungarian Soviet Republic in the Age of State Socialism (London: Anthem Press, 2014).

5 The classic works of Tibor Hajdu and György Borsányi were also later published in English. See: Tibor Hajdu, The Hungarian Soviet Republic (Budapest: Akadémiai Kiadó, 1979); György Borsányi, The Life of a Communist Revolutionary, Béla Kun (Boulder, CO: Social Science Monographs, 1993).

6 See for example: Peter Pastor, Hungary Between Wilson and Lenin: The Hungarian Revolution of 1918-1919 and the Big Three (Boulder, CO: East European Quarterly, 1976).

7 Bennett Kovrig, Communism in Hungary: From Kun to Kádár (Washington, DC: Hoover Institution Press, 1979), 54; Rudolf L. Tökés, Béla Kun and the Hungarian Soviet Republic (New York: Praeger, 1967), 162-4.

8 Apor, Fabricating Authenticity in Soviet Hungary, 208. See the emerging discourse about Trianon during the 1980s: Réka Krizmanics, 'Addressing the Trianon Peace Treaty in Late Socialist Hungary: Societal Interest and Available Narratives', Hungarian Historical Review, 9, 1 (2020), 90-112.

9 John Horne, 'Introduction: Mobilizing for “Total War”, 1914-1918', in John Horne, ed., State, Society and Mobilization in Europe During the First World War (Cambridge: Cambridge University Press, 1997), 3, 5-14. Horne, however, argued that the state was also strongly involved in the first mobilization of 1914 as well. See 225.

10 Jeffrey Verhey, The Spirit of 1914: Militarism, Myth, and Mobilization in Germany (Cambridge: Cambridge University Press, 2006); Benjamin Ziemann, Front und Heimat: ländliche Kriegserfahrungen im südlichen Bayern 1914-1923 (Essen: Klartext, 1997).

11 Krüger and Levsen, War Volunteering in Modern Times, 4, 8; Alexander Watson, 'Voluntary Enlistment in the Great War: A European Phenomenon?', in Christine G. Krüger and Sonja Levsen, eds., War Volunteering in Modern Times: From the French Revolution to the Second World War (Basingstoke: Palgrave Macmillan, 2011), 163-188.

12 Joshua A. Sanborn, Drafting the Russian Nation: Military Conscription, Total War, and Mass Politics, 1905-1925 (DeKalb: Northern Illinois University Press, 2003), 50. 
Meanwhile, the mobilisation of the armed forces in the post-Habsburg regions, and especially in Hungary, has rarely been discussed. Recent studies have focused on the right-wing paramilitary groups, but left-wing soldiers were not really examined. ${ }^{13}$ This article aims to shed light on the key factors behind the success of the Hungarian Soviet Republic. The paper first examines the military policy of the Bolshevik regime. It then investigates mobilisation propaganda and, finally, analyses methods of recruitment. To provide a more balanced picture, it discusses the situation both in Budapest and in the rural areas in the eastern half of the country.

\section{Bolshevik or Social Democratic? The Military Policy of the Hungarian Soviet Republic}

If one is to arrive at a nuanced understanding of the military policy of the Hungarian Soviet Republic, first it is important to consider the character of the Habsburg armed forces and then the armed forces of the short-lived democratic republic. Franz Josef s army had a very complex structure. Its core was the imperial and royal army, which was led by the common War Ministry of Vienna. It was supported by two independent reserve forces, the Landwehr in the Austrian half of the monarchy and the Honvédség in the Hungarian half. The officer corps had a strong supranational identity and was perceived as a pillar of the empire. ${ }^{14}$ The army, however, was not immune to the newly emerging nationalisms. For example, the Magyar political elite perceived the Honvédség as a 'true' national institution and wanted to transform it into an independent armed force. ${ }^{15}$ At the local level, however, national and imperial identities were not necessarily in conflict with each other. Veteran associations and regiments were connected closely to certain regions or towns, and they could harmonise these seemingly conflicting concepts for the common soldiers. ${ }^{16}$

Many of these regiments continued to serve - often just with a skeletal crew - after the collapse of the empire, and they became the bulk of the Hungarian armed forces under the Károlyi government. Budapest simply subordinated the common units to the existing Honvéd military administration. In the early winter of 1919, the reorganisation of this army became a crucial issue for the Hungarian government. South-Slavic, French, Romanian and Czechoslovak troops were already occupying large territories of the former Hungarian kingdom. On 20 March, Budapest was ordered to vacate further territories and limit its control to the approximate territory of today's Hungary. This led to the abdication of the disillusioned president Mihály Károlyi. ${ }^{17}$

For the new socialist-communist government established on the next day, the reorganisation of the army became a burning issue. The coalition partners, however, had very different concepts about the future of the army. Hungarian social democrats were strong supporters of the militia concept. They wanted to continue reforms which had been launched under the democratic government. In winter, conscription was abolished, high-ranking officers were disbanded, and new working-class soldiers

$\overline{13}$ Robert Gerwarth, 'Fighting the Red Beast: Counter-Revolutionary Violence in the Defeated States of Central Europe', in Robert Gerwarth and John Horne, eds., War in Peace: Paramilitary Violence in Europe after the Great War (Oxford: Oxford University Press, 2012), 52-71; Béla Bodó, The White Terror: Antisemitic and Political Violence in Hungary, 1919-1921 (Abingdon: Routledge, 2019).

14 István Deák, Beyond Nationalism: A Social and Political History of the Habsburg Officer Corps, 1848-1918 (New York: Oxford University Press, 1990).

15 On the use of the languages in the multi-ethnic regiments, see: Tamara Scheer, 'Die k.u.k. Regimentssprachen: Eine Institutionalisierung der Sprachenvielfalt in der Habsburgermonarchie (1867/8-1914)', in Marek Nekula and Martina Niedhammer, eds., Sprache, Gesellschaft und Nation in Ostmitteleuropa. Institutionalisierung und Alltagspraxis (Göttingen: Vandenhoeck \& Ruprecht, 2014), 75-92; Tibor Balla, 'A Dualizmus korának hadtörténete (1867-1914)', in Róbert Hermann, ed., Magyarország hadtörténete (Budapest: Zrínyi Kiadó, 2015), 241.

16 Laurence Cole, Military Culture and Popular Patriotism in Late Imperial Austria (Oxford: Oxford University Press, 2014); Wencke Meteling, 'Regimenter Als Image Prägende Standortfaktoren', Geschichte Und Region/Storia e Regione, 14, 1 (2005), 44. On the Hungarian case see: Tangl Balázs, 'Ezredideológiák és ezredkultúrák a cs. (és) kir. hadseregben', Hadtörténeti Közlemények, 129, 3 (2016), 682-4.

17 Liptai, A magyar Vörös Hadsereg harcai, 47-8; Pál Hatos, Az elátkozott köztársaság - az 1918-as összeomlás és forradalom története (Budapest: Jaffa Kiadó, 2018), 406-12. 
were recruited. This attempt, however, failed spectacularly. In the countryside, regular units resisted the plans, and only few thousand new volunteers enlisted. ${ }^{18}$

In contrast to the social democrats, the Bolsheviks wanted to adapt the system of Lenin's Red Army and immediately introduce conscription. Unlike in Russia, however, the communists in Budapest did not have absolute power in the government, so they had to make concessions. Social democratic journalist József Pogány ${ }^{19}$ became the commissar for war, and only his two deputies, Tibor Szamuely and Béla Szántó, were delegated by the Communist Party. The first mobilisation decree, issued on 24 March 1919, was also the result of a compromise. The less important ideological parts followed the communist concept. For example, the Red Army was defined as a class army of the proletariat. The introduction stated that every soldier must fight for the 'liberation of the world proletariat'. ${ }^{20}$ Meanwhile, the most important elements of the decree were adopted from the previous programme of the social democrats. The army expected volunteers, primarily union members and soldiers currently serving in military or paramilitary formations. The social democrats also wanted an ideologically committed force, so every recruit was required to have a recommendation from the local party organisation, trade union or a workers' council. The former professional officers of the Habsburg Army were all drafted, but military ranks and insignia were abolished. ${ }^{21}$

The new army was divided into six divisions. Two were mobilised - at least partly - in the capital city (the second and third divisions) and one in the eastern flatlands (the sixth division). This followed the scheme drawn up by the military administration of the Károlyi government. Also, the former gendarmerie was renamed the Red Guards, and it was subordinated to the War Commissariat. ${ }^{22}$ International battalions were organised, consisting of Hungarian veterans of the Russian Civil War, ethnic Russian POWS and Austrian volunteers from Vienna. These troops were mostly led by Magyar officers. Moreover, workers' battalions were established in the major factories of Budapest. These people continued to work in the factories and only participated in regular military training in their free time. ${ }^{23}$

Recruitment began relatively slowly. Altogether 48,477 soldiers (17,500 from Budapest and about 7,200 from the eastern countryside) joined the army by mid-April $1919 .{ }^{24}$ On 16 April, however, Romanian troops began their offensive. Hungarian units put up only weak resistance and retreated. Ten days later, the Czechoslovak army also joined the offensive. These forces occupied the sub-Carpathian region and Miskolc, the industrial centre of north-eastern Hungary. The situation of the Hungarian Soviet Republic seemed hopeless. ${ }^{25}$

The leadership of the regime reacted slowly. They waited two days after the beginning of the Romanian offensive to discuss the military emergency. Kun proclaimed during the government's meeting on 18 April that the regime was under attack. He immediately stated that the Hungarian Red Army was not fighting for the territorial integrity of the country but to defend the state of the

18 Tamás Révész, Nem akartak katonát látni? A magyar állam és hadserege 1918-1919-ben (Budapest: Bölcsészettudományi Kutatóközpont, 2019), 105-9.

19 See his life in: Thomas Sakmyster, A Communist Odyssey The Life of József Pogány/John Pepper (Budapest: Central European University Press, 2013).

20 Liptai, Vöröskatonák előre, 74-6, 82; Sándorné Gábor, Tibor Hajdu and Gizella Szabó, eds., A Magyar Munkásmozgalom Történetének Válogatott Dokumentumai. A Magyar Tanácsköztársaság 1919. március 21-1919. augusztus 1., vol. 6/A (MMTVD 6/A) (Budapest: Szikra, 1956), 31-2.

21 Gábor, Hajdu and Szabó, 30-2.

22 Kerekes József, Magyarország forradalmi harcai. Az 1918-1919. évi hadműveletek. (The revolutionary struggle of Hungary, Military operations in 1918-1919), Hadtörténeti Levéltár, Tanulmánygyüjtemény (HLTgy.) (Hungarian Military Archive, Manuscripts) 2322. 190. d. I. k 15.

23 Ákos Fóris, 'Orosz hadifoglyok Magyarországon 1918 végén', Világháború, világforradalom, világbéke, eds. Tamás Krausz, Zsófia Mészáros and Márton Katkó (Budapest: ELTE Kelet-Európa Története Tanszék, 2017), 69-72; Jenő Derkovics, 'A magyar vörös hadsereg gyári munkásezredeinek szervezése’, Hadtörténeti Közlemények, 2, 3-4 (1955), 214.

24 HL Magyarországi Tanácsköztársaság (MTK) (Hungatial Military Archive, Collection of the Hungarian Soviet Republic), B/102. d. 3199-223.

25 Tibor Hajdu, A Magyarországi Tanácsköztársaság (Budapest: Kossuth Kiadó, 1969), 164-8. 
proletariat. After a short debate, it was decided that the 'entire working-class' had to be mobilised, and union leaders were called on to volunteer to the Red Army. ${ }^{26}$

Meanwhile, Vilmos Böhm was appointed to the head of the Trans-Tisza Military Headquarters. Böhm was a leading figure of the social democratic Union of Metal Workers. In November 1918, he became the undersecretary and then the Minister of Military Affairs. In this position, he was responsible for the failed socialist reform of the army during the winter of 1919. Böhm supported cooperation with the Communist Party and remained very influential after the regime change. ${ }^{27}$ His most important advisor, however, was Aurél Stromfeld, a former staff colonel of the Habsburg Army. He was a very atypical officer. Stromfeld had been born into a relatively poor, middle-class family in Budapest. He graduated from the Honvéd 'Ludovika' Military Academy of Budapest and then studied at the Kriegsschule in Vienna. After the end of the First World War, he was one of the few officers who openly supported the social democrats and designed their army reform plans. After the communist takeover, Stromfeld temporarily retired, and he only joined the Red Army after the beginning of the Romanian offensive. As a former professor at the Ludovika Academy, he had considerable personal influence over many members of the officer corps. ${ }^{28}$

Over the course of the following weeks, workers' councils in Budapest all announced that their leadership would collectively join the Red Army. Thanks to the government's efforts, the number of Red soldiers rose to 60,000 by the end of April. ${ }^{29}$ This was not enough, however, to stop the Romanian and Czechoslovakian advance. On 2 May 1919, Romanian troops reached the Tisza River and ceased their offensive only about $100 \mathrm{~km}$ from Budapest. Some of the moderate social democrats proposed that the government resign. Béla Kun and the radicals, however, remained determined to continue the fight. They decided to mobilise the 'entire working-class', and they sent every people's commissar to a major union or to a large factory to convince the union members to enlist. ${ }^{30}$

The mobilisation in early May turned out to be spectacularly successful. Approximately 60,000 new soldiers joined the Red Army, almost half of them $(29,000)$ enlisting in the capital city. Mobilisation in the eastern countryside was also very successful. The number of soldiers in the sixth division grew from 7,200 to 23,000 within a month. These numbers are even more remarkable if we consider that most of the division's recruitment territory was already occupied by Romanian forces. ${ }^{31}$ The Red troops were led by former Habsburg officers who were drafted in late April 1919. These men, mostly captains, majors and colonels, joined the Red Army due to the existential threat and the opportunity to rise rapidly in the ranks. Many of them had been born in the already occupied territories, so they were extremely motivated to fight. ${ }^{32}$

By mid-May, this new Red Army already consisted of more than 120,000 frontline soldiers. Later that month, this force started an offensive against the Czechoslovak troops and occupied the towns of Kassa (Košice) and Eperjes (Prešov). While the army fought successfully on the frontline, at home, the number of volunteers started to drop. At the beginning of June, the communists introduced compulsory military service, and the local workers' councils were entrusted with mobilisation. House stewards appointed representatives of the Social Democratic Party in every apartment block - were put in charge of overseeing conscription. They were instructed to hang the names of those not willing to join the army in the stairways of their homes. Despite these efforts, conscription turned out to be very ineffective.

${ }^{26}$ Gábor, Hajdu and Szabó, MMTVD 6/A, 259-60; Magda Imre and László Szűcs, eds., Magyar minisztertanácsi jegyzőkönyvek 1867-1919: 3: A Forradalmi Kormányzótanács jegyzőkönyvei 1919 (Budapest: Akadémiai Kiadó, 1986), 321.

27 László Szűcs, 'Bőhm Vilmos politikai pályája', in Éva Szabó and László Szűcs, eds., Válogatott Politikai Levelei, 1914-1949 (Budapest: Napvilág Kiadó, 1997), 7-22.

28 Hetés, Stromfeld Aurél, 5-6, 9-12, 44, 50-1; Liptai: Vöröskatonák elöre, 116.

29 Mária H. Kohut, ed., Források Budapest múltjából, vol. II (Budapest: Budapest Főváros Levéltára, 1971), 472-3; HL MTK B/102. d. 3224-48.

30 Imre and Szűcs, Magyar minisztertanácsi jegyzőkönyvek 1867-1919, 380-1.

31 HL MTK B/102. d. 3199-223.

32 Sándor Szakály, 'The Officer Corps of the Hungarian Red Army', in Peter Pastor, ed., Revolutions and Interventions in Hungary and its Neighbour States 1918-1919 (Boulder, CO: Social Science Monographs, 1988), 169-178. 
Only a handful of people appeared in front of the recruitment commissions, and most of them turned out to be unfit for service. ${ }^{33}$

Meanwhile, the offensive was stopped in the north and the Paris Peace Conference ordered the retreat of the Hungarian troops to the original demarcation line. Béla Kun reluctantly agreed and withdrew the Red Army in exchange for occupied eastern Hungary. Bucharest, however, had different plans and refused to vacate these territories. Consequently, morale in the army deteriorated, and many disillusioned officers decided to resign. To turn the tide, the Bolshevik regime started its last desperate offensive on 20 July 1919. After a few days, the Hungarian attack collapsed and the Romanian army marched into Budapest, occupying the capital city on 4 August $1919 .^{34}$

\section{Mobilisation Propaganda}

During its short reign, the Hungarian Soviet Republic put massive emphasis on the indoctrination of the population. A special State Propaganda Bureau was established with a separate department for military issues. It published several flyers and posters, many of them written or designed by the leading progressive artists of the time. These people were mostly young, middle-class intellectuals, most of whom had no first-hand experience of the Russian Bolshevik revolution and were not (or were only loosely) connected to the Communist Party. ${ }^{35}$

Given this, it is less surprising that the mobilisation propaganda mixed dogmatic communist ideology with many traditional elements inherited from the pre-1918 period. Most of the posters and flyers published by the central authorities followed a Bolshevik-revolutionary narrative. They argued that the soldiers should enlist to fight for the liberation of the oppressed and exploited people of the world. These texts portrayed the conflict as a war fought between classes, not nations. The flyer entitled 'How the Red Army Is mobilised' stated that the main aim of the Red Army was 'to defend against the damned enemies of the proletariat'. It argued that, in this fight, the 'army of exploiters had to be destroyed to establish the possibility of eternal peace in a socialist state. ${ }^{36}$ The propaganda always presented the situation of the already occupied Transylvania and territories in northern and southern Hungary in this framework. József Pogány stated in early April that these territories had to be liberated to nationalise industry and take it from the hands of the Czech bourgeoisie, the Romanian Boyars and the Serbian generals. ${ }^{37}$

The recruitment propaganda in the eastern countryside was not necessarily more nationalistic than in the capital city. The mobilisation order of the Debrecen Directorate simply stated that the Red Army was going to fight for the liberation of the world proletariat. ${ }^{38}$ The local workers' and soldiers' council even supported the abolishment of military insignias, because they considered them symbols of class oppression. ${ }^{39}$ Local politicians often followed this revolutionary line. As the flyer of the eastern Hungarian Hajduböszörmény soldiers' council argued, the sacrifices made by the soldiers would be rewarded with the freedom of the world proletariat. ${ }^{40}$ Like the articles published in Budapest, in the eastern Hungarian town of Debrecen the propaganda also connected the liberation of the country to the freedom of the oppressed classes. On rare occasions, these texts combined communist rhetoric

33 Ervin Liptai, 'Kun Béla és a Tanácsköztársaság védelme’, in Tibor Erényi, ed., Kun Béláról: tanulmányok (Budapest: Kossuth, 1988), 262-3; Liptai, Vöröskatonák Elöre!, 215-16.

34 Tibor Hajdu, Az 1918-as Magyarországi Polgári Demokratikus Forradalom (Budapest: Kossuth, 1968), 180-7.

35 Viktor Szabó, A kommunizmus büvöletében. A Magyarországi Tanácsköztársaság propagandája (Budapest: TIT Teleki László Ismeretterjesztő Egyesület, 2019), 47-9, 52.

36 Hadtörténelmi Múzeum, Plakát- és Aprónyomtaványtár. (HM PA) (Museum of Military History, Poster and Flyer collection) $76.72 .1 /$ Nyt 3.

37 Pogány József: Miért kell Vörös Hadsereg? (Why do we need the Red Army?); Politikatörténeti Intézet Levéltára (PIL) (Archive of the Political History Institute) II/20/1919/1057.

38 Népakarat, 27 Mar. 1919, 3.

39 'A munkás és Katonatanács ülése', Népakarat, 25 Mar. 1919, 2.

40 A Tanácsköztársaság Hajdú-Biharban: 1919 (Debrecen: Magyar Szocialista Munkáspárt Hajdú-Bihar Megyei Bizottsága, 1959), 391. 
with nationalistic expressions. For example, the local socialist newspaper Will of the People (Népakarat) argued that the aim of the struggle was 'to unite all the proletariat and liberate our 1000-year-old homeland'. ${ }^{41}$

The rhetoric of the propaganda did not become more nationalistic after the beginning of the Romanian offensive on 16 April. The regime remained committed to the internationalist cause, as was most impressively demonstrated in the great May Day parade. In the prominent squares, statutes of communist leaders temporarily replaced traditional national heroes. A large sign was also put over the statue of Karl Liebknecht with the following text: 'The Red soldier does not fight against his proletarian brothers but against international capital. ${ }^{42}$ The centrally organised propaganda was not the only institutional form of discourse which followed this line. The leadership of the Brush and Broom Factory (Kefe és Seprügyár) union, for example, made a public call to its members in which it argued that they should 'fight for the better future of mankind, for their family and themselves'. ${ }^{43}$

Although nationalism did not appear in the texts, the rhetoric shifted slightly after the beginning of the Romanian offensive. The posters put more emphasis on the defence of the proletariat's state than on the victory of world revolution. According to one text, 'You are the soldiers of the revolution. The revolution gave you the weapons to defend the revolution of the proletariat, to abolish every form of class oppression and to defend the power of the working classes. ${ }^{.44}$ Communist leaders also used economic arguments to convince industrial workers of the necessity of enlistment. They claimed that soldiers should join the army because Budapest could not survive unless the mines and agricultural lands providing vital supplies to the capital city were liberated. ${ }^{45}$

Although the main messages remained leftist-communist throughout this period, many elements of First World War propaganda reappeared. For example, masculinity was connected strongly to the idea of military service. The Red soldiers were often portrayed as defenders of women and children and deserters were depicted as unworthy of calling themselves real men. ${ }^{46}$ Similarly, the portrayal of the enemy copied wartime narratives. Romanian soldiers were characterised as brutal but cowardly savages. According to one flyer, 'As usual, the Romanian army stopped immediately when they met with armed resistance'. This was clearly in reference to the failed Romanian campaign of 1916 in Transylvania. ${ }^{47}$ Contrary to the Romanians, Slovaks were portrayed as an unintelligent and misled people, who needed to be enlightened and led by the 'more developed' Magyars. This image closely resembled nineteenth-century Hungarian nationalist stereotypes. ${ }^{48}$

The Romanian offensive slightly changed the tone of the propaganda in the borderland as well. The local trade unions and military commands often combined socialist ideas with patriotism and called on the soldiers to defend the achievements of the revolution. ${ }^{49}$ Despite these tendencies, the propaganda still rarely portrayed the struggle in the national framework. The newspapers published for eastern Hungarian soldiers were no exception in this regard. The agenda of these texts remained very local. They emphasised the liberation of the county, town or family and barely mentioned the future of 'Greater Hungary. ${ }^{50}$ As in Budapest, the texts targeting the industrial workers used arguments based on economic interests. They emphasised that the regime would take care of the soldiers' families, while they were fighting for a better future for every citizen. István Vági, a communist political leader

\footnotetext{
41 Népakarat, 26 Mar. 1919, 1, 4.

42 Boldizsár Vörös, A múltat végképp eltörölni’? történelmi személyiségek a magyarországi szociáldemokrata és kommunista propagandában, 1890-1919 (Budapest: MTA Történettudományi Intézet, 2004), 91.

43 Gábor, Hajdu and Szabó, MMTVD 6/A, 293.

44 Az erdélyi front Vörös Katonáihoz! (To the Red soldiers of the Transylvanian frontline!), PIL II/20/1919/1062.

45 Pogány József: Miért kell Vörös Hadsereg? (Why do we need the Red Army?), PIL II/20/1919/1057.

46 HM PA 3475/Nyt.

47 PIL II/20/1919/1082.

48 HM PA 1705/Nyt.; Ágnes Tamás, Nemzetiségek görbe tükörben: 19. századi nemzetiségi sztereotípiák Magyarországon (Pozsony: Kalligram, 2014), 158-9, 161.

49 György Komoróczy, ed., A Tanácsköztársaság Hajdú-Biharban: 1919 (Debrecen: MSZMP Hajdú-Bihar Megyei Bizottsága, 1959), 412, 416-17.

50 'Hazátlanul' Bihari Vörös Újság, 5 Jun. 1919, 2.
} 
from Debrecen, argued that 'while you [the soldiers] are defending our borders from the greed of Boyar imperialism, we are defending our new social order here on the home front. This regime will provide a better life for everybody. ${ }^{51}$

\section{Mobilising the Red Army in Budapest}

The intensive recruitment to the Red Army began almost immediately after the mobilisation decree was published on 24 March 1919 and recruitment committees were established in the barracks. Initially, this meant that the soldiers already serving in the army were simply reregistered. New recruits joined the military in relatively small numbers. Many of them were industrial workers. These people often enlisted individually or in small groups, following the example set by their older colleagues. ${ }^{52}$

The Soviet regime also tried to organise public events to encourage more people to join the army. In Budapest, the first massive recruitment rally was held on 30 March 1919. Temporary stages were erected in the city parks, where artists performed short plays and the trade unions' bands played popular workers' songs. Following the programme, leading politicians appealed to people to enlist into the Red Army. In the evening, the middle classes were targeted as well. Recruitment speeches were held in the theatres, cinemas and the opera house. ${ }^{53}$ The recruitment rallies continued in the following week. On 6 April 1919, a large procession was held with the participation of many renowned artists of the Hungarian light opera scene. The highlight of the event was the international football match between Austria and Hungary, where half-time was used to recruit soldiers from among the fans. The whole programme of these events resembled in many ways the choreography of pre-war festivities. ${ }^{54}$

The real change in the mobilisation started after the beginning of the Romanian offensive on 16 April 1919. Following Béla Kun's call to mobilise the working class, trade union leaders and members of the workers' councils began to volunteer in massive numbers. ${ }^{55}$ The seemingly ineffective recruitment committees were abolished and the local councils, trade unions and factory councils were entrusted with registering the volunteers. These three institutions could mobilise the population with different levels of effectiveness. The least successful agents were the district councils. They established recruitment points in prominent places of the districts' political or cultural lives, such as schools and workers' clubs. However, some of these places were remote for working-class people. For example, the fifth district recruited soldiers in a café in an elegant theatre and downtown restaurants. ${ }^{56}$

Undoubtedly the more important actors of the mobilisation were the trade unions. Their recruitment followed two slightly different patterns. The large but diverse unions, the members of which worked in various places across the city (like postmen), mostly organised one mass assembly. These events were held on symbolically important squares or avenues, and their choreography copied the pattern of a social democratic mass rally. The union's chorus sang workers' songs, and then the leaders made short speeches. In the end, they announced from the stage that the whole union had collectively joined the Red Army. The smaller but more affluent unions - like the typographers' union - held their assemblies at theatres and public halls. The choreography here mostly followed the same pattern. ${ }^{57}$

While the members of the smaller associations were sorted into one of the existing regiments, the bigger unions usually wanted to establish their autonomous military formations. They therefore organised the registration of their members independently from the military authorities. For example, the

\footnotetext{
51 Komoróczy, A Tanácsköztársaság Hajdú-Biharban, 408.

52 HL MTK 1218. Vöröskatona visszaemlékezések. (Hungarian Military Archive, Collection of the Hungarian Soviet Republic, Memoire collection of red soldiers), 131. d. 48. Balogh István.

53 'A Vörös Hadsereg toborzó ünnepe', Népszava, 30 Mar. 1919, 7.

54 'Katonaünnep az utcákon', Vörös Katona, 7 Apr. 1919, 3; 'Kétszázezer ember vett részt a vasárnapi toborzómenetben', Vörös Katona, 9 Apr. 1919, 2.

55 Gábor, Hajdu and Szabó, MMTVD 6/A. 260.

56 HL MTK I. 30. Hadügyi Népbiztosság 6. osztály. (Hungarian Military Archive, War Commissariat, 6. department) 3222. $1030-1032 / \mathrm{c}-\mathrm{d}$.

57 Gábor, Hajdu and Szabó, MMTVD 6/A. 229, 308.
} 
postmen established their own recruitment board in their union hall. The members of these committees were mostly shop stewards, union leaders and medical personnel delegated to check the fitness of the volunteers. The next morning, the people who had been selected marched together into a nearby barrack. $^{58}$

Recruitment was slightly different in the large factories. Here workers' councils had all the workers assemble in the factory yard, and local union leaders held speeches together with one or more prominent politicians. The participants then proclaimed their collective enlistment into the army. These factories were always allowed to form their own companies or even battalions. In many cases, the NCOs and even some of the officers were employees of these factories, and they started the training of the workers in the factory yard. ${ }^{59}$ In practice, this meant the adaptation of the union's hierarchy and power structure into the armed forces.

The success of the enlistment methods introduced in late April and early May exceeded every earlier expectation. The largest unit in Budapest was the third division, which consisted of soldiers recruited from the south-eastern working-class areas and the surrounding industrial towns of Csepel, Pestszentlörinc and Kispest. Most of the new volunteers joined the successor unit of the 32 Infantry Regiment of the Habsburg army, in which 15,000 people served, including workers from the massive Ganz factory and all the railway workers and clerks. ${ }^{60}$

\section{Mobilising the Red Army in the Eastern Countryside}

After 21 March 1919, in the eastern countryside - as in the capital - the first measure taken was the reregistration of soldiers already serving in the army. These men were assembled in the garrison's square, where they took an oath to the new regime and then were sent before the enlistment committees. ${ }^{61}$ Meanwhile, new volunteers were called to go to the barrack of their previous regiment and bring their uniforms with them. For many people, enlistment into the Red Army brought no change at all. These First World War veterans simply rejoined their old units. ${ }^{62}$ The municipalities also continued wartime traditions, treating these 'new', 'Red' regiments as their 'own' units. For example, the citizens of Debrecen were called upon to donate underwear to local soldiers, which had been a familiar practice in many Austro-Hungarian towns between 1914 and $1918 .^{63}$

In some smaller industrial centres, trade unions played a key role as well. In early April, the union leaders, in cooperation with the military commanders, decided that all their members should join the army together. To organise recruitment effectively, people of each profession were assigned to enlist on different days. These workers were mostly held in reserve until the beginning of the Romanian offensive. As was the case in Debrecen, union members in other industrial towns like Arad and Oradea also joined the Red Army in massive numbers. ${ }^{64}$

In the countryside, recruitment committees were established with the participation of the newly elected local peasants' councils and officers of the local regiment. ${ }^{65}$ The councils' members were not all committed communists but mainly respected figures of the local community, like schoolteachers or well-to-do craftsmen. According to a previously published schedule, these committees went to a new village every day. They usually settled in a public or popular building and waited for volunteers to report. For example, in the rural community of Hajduböszörmény, a pub was chosen

\footnotetext{
58 HL MTK 1218. Vöröskatona visszaemlékezések. 128. d. 83. Farkasházy Antal.

59 HL MTK 1218. Vöröskatona visszaemlékezések. 128. d. 30. Jenicsek Lajos.

60 HL MTK B/102. d. 3224-48.

${ }^{61}$ HL MTK 1218. Vöröskatona visszaemlékezések 129. d. 57. Süli József; MNL Hajdú-Bihar Megyei Levéltár (HBML) (Hungarian National Archive, Hajdú-Bihar County Archive) XVI. 51. Debreceni Munkás és Katonatanács iratai (Council of Workers and Soldiers, Debrecen. Documents) 1./a 187.

62 'Felhívás!', Népakarat, 26 Mar. 1919, 1.

63 'Fehérnemüt és ruhát a vörös hadseregnek', Népakarat, 10 Apr. 1919, 2.

64 Komoróczy, A Tanácsköztársaság Hajdú-Biharban. 389, 407; HL MTK Visszaemlékezések 130. d. 27. Aczél Alfréd,

65 MNL HBML XVI, 53, 62.
} 
for this purpose. ${ }^{66}$ In some places, like in the ethnic Slovak village of Tótkomlós, the recruitment resembled the earlier patterns of political mobilisation. After publishing the recruitment call, the young men of the village gathered in the main square, took a photograph, and marched to the nearby garrison of Békéscsaba. These people - as had been common in rural communities since the 1860s joined their 'own regiment', which had been renamed from the Imperial and Royal 101 Infantry Regiment to the 101st Red Regiment. ${ }^{67}$

In many villages, the retreating regular units could recruit from the existing self-defence and police formations. The region has been in a highly militarised state since January 1919, when the demarcation line had been drawn between the Hungarian and the Romanian Armies. Local paramilitary guards together with many former Habsburg regiments were stationed there. Many of them had withdrawn from the occupied territories of Transylvania. Earlier, the so-called 'National Guards' were mobilised in the towns and villages during the autumn of 1918. They were established as a reaction to the massive peasant uprising in the countryside accompanying the Aster Revolution in early November 1918. Many municipalities organised paramilitary units to stop these early rebel-type revolts. $^{68}$

Many of these formations existed until the spring of 1919. At the time of the Romanian attack, these small groups decided to retreat from the advancing Romanian troops, and they were simply incorporated into Red Army formations. They mostly kept their internal hierarchies and were only renamed, becoming a particular company in the local regiments. ${ }^{69}$ Senior classes of the local cadet schools - which had been used for policing since November 1918 - joined the retreating Red Army units too. According to some sources, similar phenomena could be observed in some civilian high schools as well. ${ }^{70}$ At times, the local police and the Red Guard were also merged into Red Army regiments. These servicemen were often far from committed revolutionaries. Most of them had served in the gendarmerie before 1918 and had continued to do so under the Károlyi government. $^{71}$

In addition to these groups, municipalities were also able to find new recruits among the refugees from Transylvania. These refugees, most of whom were middle-class men, had fled from the Romanian army during the winter of 1918-19 to the major towns of the Trans-Tisza region. These people joined the Red Army in massive numbers for two main reasons. First, many of them had been traumatised by their experiences of having to flee their homes and were eager to fight against the army occupying their homeland. Second, they relied on the material support of the local authorities, both in terms of food rations and temporary housing. The municipalities could take advantage of these people's dependency. The workers' councils of Szilágysomlyó (Șimleu Silvaniei), for example, advised the town of Zilah (Zalău) to stop providing financial support for refugees who failed to enlist. $^{72}$

\section{Coercion, Peer Pressure and Propaganda. Why Was the Mobilisation Successful?}

The reasons behind the successful mobilisation of the Hungarian Soviet Republic were undoubtedly complex. A very intensive propaganda campaign, direct and indirect coercion through different institutions and massive social pressure played important roles. Undoubtedly it is hard to estimate the real impact of the propaganda, but the arguments and appeals used in these flyers and posters were

\footnotetext{
66 Komoróczy, A Tanácsköztársaság Hajdú-Biharban, 391.

67 HL MTK 1218. Vöröskatona visszaemlékezések 132. d. 22; 133. d. 54. Jambrik István.; József Zsigmond, Magyaró néphagyományaiból: szemelvények (Marosvásárhely: Mentor, 1996), 138.

68 See: Révész, Nem akartak katonát látni?, 153-63. This uprising was similar to the actions of the Green Cadres. See Jakub S. Beneš, 'The Green Cadres and the Collapse of Austria-Hungary in 1918', Past \& Present, 236, 1 (2017), 207-241.

69 For example: HL MTK 1218. Vöröskatona visszaemlékezések 132. d. 80. P. Szabó János.

70 HL MTK 1218. Vöröskatona visszaemlékezések 130. d. 27. Aczél Alfréd.

71 Komoróczy, A Tanácsköztársaság Hajdú-Biharban, 407. 'Megmozdult Debrecen proletariátusa', Népakarat, 18 Apr. 1919.

72 MNL HBML XVI. 51. Debreceni Munkás és Katonatanács iratai 1./a 181.
} 
certainly not alien to many union members. For a long time, these people had been exposed to the agitation of the Social Democratic Party. To them, the choreography of recruitment rallies may have been familiar from the pre-1914 demonstrations. Moreover, for many war veterans, the slogans and the iconography may have been well-known from their wartime service. ${ }^{73}$

In Budapest, the key to the mobilisation was undoubtedly the involvement of the trade union networks. These associations were practically the extended branches of the Social Democratic Party in Hungary. After a brief drop at the beginning of the war, their membership grew from the initial prewar 107,000 to 721,437 in $1918 .^{74}$ Industrial workers were not the only people to become union members in large numbers. After the Károlyi government allowed the establishment of new associations, other professions formed organisations as well. In July 1919, membership in these kinds of organisations reached 1.4 million, only 39 per cent of whom were industrial workers. ${ }^{75}$ This meant that the vast majority of the urban male population of Budapest was in a trade union. According to the statistics, most of these people had received military training during the war, and many of them served in the frontlines.

These unions could fundamentally shape the everyday lives of many people in three distinct ways. First, at the end of the First World War, unions had a major impact on the labour market and the working conditions in urban centres. They represented the employees of major factories in the so-called complaint committees. These institutions were established in 1916 to mediate between employers and employees, and they had the power to modify production norms, set wages and excuse workers from duty on the front. This power became a key issue in the second part of the war, when the Honvéd Ministry commanded more and more people back to armament production. ${ }^{76}$ Union leaders had a huge influence on the selection of these workers, and so the members had a better chance of avoiding the horrors of the frontline service. In consequence, many of these battle-hardened veterans were grateful for their release and became loyal to their associations. ${ }^{77}$ The influence of unions continued to grow even after the end of the hostilities. Following the establishment of the Hungarian Soviet Republic, the industry was formally nationalised, and practically only union members could be employed in most jobs. ${ }^{78}$ Consequently, those who refused the mobilisation call could count on expulsion from the union and also had to face immediate unemployment. It was almost impossible to go into hiding because union clerks were present at every workplace, and colleagues could report people who shirked military duty.

Second, unions had a large influence on the housing market. To regulate the spiralling rents in Budapest, in the spring of 1917 a new committee was established to coordinate the distribution of empty flats. On this board, renters were represented by the so-called Renters' Association, a satellite organisation of the Social Democratic Party. As in the case of the complaint committees, the union leaders favoured their members and provided them with better and cheaper housing. ${ }^{79}$ After the return of the soldiers from the frontline, the housing crisis became more serious in urban centres. In the spring of 1919, many people hoped that they would benefit from the flat requisitions and that military service would open new, better accommodations for them and their families. ${ }^{80}$

\footnotetext{
73 See, for example, the poem of Fedinánd Papp, a locksmith from Újpest, written on 26 Apr. 1919. Magyar Nemzeti Múzeum Történeti Tár (Hungarian National Museum, Historical collection), I/IV/1520.

74 Péter Sipos, Die sozialdemokratische Partei Ungarns und die Gewerkschaften, 1890-1944 (Budapest: Akadémiai Kiadó, 1991), 29; Márton Buza, A Magyarországi Vas- és Fémmunkások Központi Szövetségének története (Budapest: Szakszervezetek Elméleti Kutató Intézete, 1990), 168.

75 Janiszné Bakalisz, 'A szakszervezetek szervezeti felépítésének alakulása a Tanácsköztársaságban', in A magyar szakszervezetek a Tanácsköztársaságban, ed. Kende János (Budapest: Táncsics K., 1970), 56, 60.

76 Irén Nevelő, A háború és a magyarországi munkásság: 1914-1917 (Budapest: Kossuth Könyvkiadó, 1980$), 74$.

77 Lajos Varga, Háború, forradalom, szociáldemokrácia Magyarországon, 1914. július-1919. március (Budapest: Napvilág, 2010), 32-8.

78 Bakalisz: A szakszervezetek, 60.

79 Zsombor Bódy, 'Szociálpolitika és szociáldemokrácia Magyarországon az I. világháború idején', Századok, 139, 1 (2005), $1470-1$

${ }^{80}$ HL MTK B/135. d. 1755. 913.
} 
Third, the unions played a key role in the food supply for the working-class suburbs. After the outbreak of war, the Hungarian government realised that it could not organise food distribution in the major urban centres. Consequently, these tasks were outsourced to different private organisations very early. In industrial areas, the so-called General Consuming Cooperative, a satellite organisation of the Social Democratic Party, coordinated food distribution. In 1918, it became almost solely responsible for providing food and consumer goods to many working-class districts of Budapest and nearby industrial towns like Csepel and Pestszentlörinc. ${ }^{81}$ This power was exploited by political leaders. In May, reluctant volunteers were even threatened in some places with being starved if they refused to join the Red Army. ${ }^{82}$ On the other hand, at least theoretically, family members of the soldiers had privileged food allowances. ${ }^{83}$ In addition to the union's coercive power, peer pressure could also play a major role. These working-class districts were relatively closed communities, where people lived in the same neighbourhood and worked at the same factories or companies. Refusing the call to mobilise could lead to public shame and loss of an individual's social status.

Although the overall situation in the countryside differed fundamentally from the urban centres, some factors were common to both regions. In eastern Hungary, unions could similarly force their members to volunteer for the Red Army. Transylvanian refugees living in smaller towns were also highly dependent on the support of the local authorities, thus making them very vulnerable to pressures and easy to mobilise. The propaganda campaign could also have a positive impact, but in a slightly different form. Although nationalism was not dominant in the rhetoric, the texts used traditional elements inherited from the pre-1918 period. These flyers and posters in the countryside also put more emphasis on the nature of the conflict as a struggle fought in self-defence than the flyers distributed in towns. Playing on the defensive patriotism of these people served as a very effective tool, as was also the case in other European countries at the beginning of the First World War. ${ }^{84}$

In eastern Hungary, the key institutions of the mobilisation campaign were undoubtedly the regular army formations. These formations were successors to the former Habsburg regiments. As was true everywhere in Europe, these units became the pride of many regions, and the officer corps were integrated into the local elite. These connections did not disappear after the collapse of the Habsburg Empire. Regiments remained respected institutions in the local communities. The volunteers in 1919 mostly joined these old wartime units, following the choreography of peacetime enlistment. Moreover, most of these 'new' recruits were never really demobilised. Almost immediately after having returned from the front, these men joined one of the paramilitary units. These troops rarely left their villages or towns, but at the time of the Romanian and Czechoslovakian offensives they joined the retreating regular army formations. Many of these squads were led by professional Habsburg officers. After their expulsion, these people became strongly committed to the 'liberation' of their lost homeland.

\section{Conclusion: Continuity and Change After the First World War}

As the previous sections demonstrated, the military mobilisation in the Hungarian Soviet Republic was neither nationalistic nor Bolshevik. Despite the claims of Western European observers, the leadership of the regime did not pursue nationalistic goals. It perceived the armed conflict as a class struggle between the proletariat and the oppressive bourgeoisie. They believed in a coming world-revolution, and until this envisioned revolution came, they sought to preserve their position in power. The regime's intentions were not hidden at all. The recruitment posters and flyers followed very dogmatic lines, though they undoubtedly adapted many traditional elements of wartime propaganda. This special mixture was especially characteristic of the propaganda used in the countryside. In particular, the defensive nature of the struggle was emphasised there more frequently than in urban centres.

\footnotetext{
81 Bódy, 'Szociálpolitika és szociáldemokrácia Magyarországon', 1471-2; Rudolf Kučera, Rationed Life: Science, Everyday Life and Working-Class Politics in the Bohemian Lands, 1914-1918 (New York: Oxford, 2016), 12-56.

82 Magyar Nemzeti Levéltár, Országos Levéltár (Hungarian National Archives, State Archives), K 46 PTI f.605. 12. d. II/28.

83 HL MTK B/100. d. 3087. 136.

84 Watson, 'Voluntary Enlistment in the Great War: A European Phenomenon?', 175.
} 
This dogmatic approach, however, did not necessarily mean that the Hungarian Red Army was mobilised following Bolshevik principles. Unlike in Russia, where Lenin and his comrades had very strong positions, in Hungary, the communists had to form a coalition government with the Social Democrats. Thus, they could not implement their military concept but rather had to reach a compromise with their allies. The most effective mobilisation was also conducted through the use of the Social Democratic union networks. These associations organised the lives of everyday people in the workingclass districts of Budapest. These networks were able to transfer the messages of the propaganda and use direct and indirect means of coercion to force their members to enlist. In rural towns, local craftsmen and workers could be recruited using similar means. Additionally, many refugees from the already occupied territories decided to join the armed forces. In the countryside, most of the mobilisation was, however, rather traditional. Peasants joined their old regiments following the same choreography of enlistment as had been used before 1918. Moreover, many of these war veterans were never really demobilised. Their paramilitary units were just incorporated into the retreating local regiments.

In that sense, the keys to successful post-war recruitment were the institutions and communities that were reinforced by the second wave of wartime mobilisation and were able to survive the collapse of the Empire. After 1916, states began to privilege certain groups and institutions to gain support for the war effort. For example, the industrial mobilisation after 1916 put the trade unions into a very powerful position. The governments had to use them to ensure the loyalty of the industrial workers, who were essential to the war effort. After the collapse of the Austro-Hungarian Empire, these unions continued to control the everyday lives of many citizens in the region. In a time of turmoil and state-collapse, they still provided food and protection to their members, as well as a form of identity and, thus, solidarity. This was not restricted to the major industrial centres; industrial workers fought in different borderland wars as well. ${ }^{85}$ In Budapest, however, trade unions played a more important role in the mobilisation than anywhere else in East Central Europe. Two main factors led to this development. First, under the radical leftist regime, unions formed among non-working-class people as well, enabling the regime to reach the middle classes. Second, due to the close and imminent threat of invasion, the recruitment was conducted on a much larger scale and in a relatively short period of time.

Although the success of the Hungarian Bolsheviks was a product of the second wave of wartime mobilisation, their methods showed remarkable similarities with the initial 'civil' mobilisation of 1914. Thus, for example, the organisation of the Red Army could be paired with the establishment of Kitchener's New Army in Great Britain. The Pals' Battalions were recruited in a very similar fashion, and the number of volunteers also increased more radically after the first defeats of the British Army in France. ${ }^{86}$ The similarity between the two cases could be explained by the comparable circumstances. In 1914, the British government did not have the means to introduce conscription, so it used the existing networks of civil society to mobilise large parts of the population. Due to the collapse of the public administration, seeking volunteers turned out to be a more effective method in Hungary as well, and to mobilise the population, the new revolutionary regime desperately needed the cooperation of non-state actors. The situation in Bolshevik Russia was very similar. Lenin's army grew exponentially when the conscription was decentralised and the task was allocated to factories, town municipalities, trade unions and local military commanders. ${ }^{87}$

Moreover, many Hungarian soldiers - especially in the countryside - did not need any remobilisation because they were never really demobilised. Similarly to other East-Central European countries, here many old regiments survived the collapse of the empire. ${ }^{88}$ Additionally, returning soldiers often

\footnotetext{
85 See, for example, in the case of Carinthia Tamás Révész, "For the "Freedom and Unity" of Carinthia? New Perspectives on the Military Remobilization in the Carinthian Borderland War (1918-1919)', First World War Studies, 7, 3 (2017), 265286.

86 Peter Simkins, Kitchener's Army: The Raising of the New Armies, 1914-1916 (Manchester: Manchester University Press, 1988), 80, 86-7; Watson, 'Voluntary Enlistment in the Great War: A European Phenomenon?', 175.

87 Sanborn, Drafting the Russian Nation, 40-5.

88 See, for example, the case of Poland. Julia Eichenberg, 'Soldiers to Civilians, Civilians to Soldiers: Poland and Ireland after the First World War', in Robert Gerwarth and John Horne, eds., War in Peace: Paramilitary Violence in Europe after the Great War (Oxford: Oxford University Press, 2012), 188.
} 
continued to serve in various paramilitary formations, which were formed to fight against the looting peasants in November 1918. For these people, joining the Red Army was simply a continuation of their wartime service. This was also the case in the officer corps. Many former imperial officers joined the Bolshevik armies both in Hungary and Russia. The first commanders of the two Red Armies, Aurél Stromfeld and Mikhail Bonch-Bruyevich, were both experienced staff officers who helped to gradually professionalise these armed forces. ${ }^{89}$

Thus, the Hungarian case fits well with the 'Greater War' and 'long transition' interpretations of the post-1918 period which have emerged in the recent literature. The violence in the Carpathian Basin undoubtedly continued after 1918, and the First World War veterans were only really demobilised in the early 1920s. ${ }^{90}$ The important role of local regiments also supports Pieter Judson's argument about the survival of imperial institutions and mentalities in the peripheries of Austria-Hungary. ${ }^{91}$

Notions of continuity with the fallen empires, however, rarely appear in the memory of these conflicts. As in other European nations, both victorious and defeated, the post-war military mobilisation in Hungary was later reinterpreted in a national framework. This was in the interests of both Miklós Horthy's new regime and the veterans themselves. In the summer of 1919, the former admiral's national army was a very small force which desperately needed every trained soldier. The national reinterpretation of the borderland war allowed the reintegration of the officer corps and, thus, the consolidation of power. Deserters of the Red Army were quickly examined and then accepted. For example, despite serious accusations concerning treason, Henrik Werth, who was later commander-in-chief of the Hungarian Army, was quickly absolved of all charges and commissioned to serve in the armed forces. ${ }^{92}$ For the people who served in the Red Army, adjusting to this national narrative was a logical step to prevent any kind of retribution. Ferenc Julier, head of the army following Stromfeld, expressed this in a series of articles in which he contended that the national spirit of the officer corps had never disappeared under the communist regime. ${ }^{93}$ From this perspective, it is understandable how the vast majority of the Red Army's officers - including Ferenc Szombathely - could successfully continue their careers under the counterrevolutionary regime. In many ways, these people were even better integrated than many radical right-wing paramilitary leaders. ${ }^{94}$

Similar processes took place after 1945, when veterans of the Soviet Republic presented themselves as the first fighters of the communist cause. These people - mostly working-class soldiers - hoped that their service would be rewarded under the new regime with better positions and higher pensions. Their social democratic and unionist ties were almost always overwritten by a new communist veteran culture. Not all of them lived long enough to participate in this process. István Reis, the Minister of Justice who extradited Szombathelyi to the Yugoslavs, was murdered in 1950 by the communist secret police. The veteran of the Soviet Republic became a victim of the second Hungarian Bolshevik state.

Acknowledgements. I would like to thank Balázs Ablonczy and Hannes Leidinger for their continuous support during my research. I am also very grateful to Alexander Watson and the two peer-reviewers for their valuable comments on the first version of this article.

89 Tibor Hajdu, 'Katonák, hivatásos tisztek szerepe a magyar és az orosz forradalmakban (1917-1921)', Történelmi Szemle, 51.4 (2009), 519-39, 522-5.

90 See the studies in Robert Gerwarth and John Horne, War in Peace: Paramilitary Violence in Europe after the Great War (Oxford: Oxford University Press, 2012).

91 Pieter M. Judson, The Habsburg Empire: A New History (Cambridge, MA: Harvard University Press, 2016).

92 Lóránd Dombrády, Werth Henrik, akiről nem beszéltünk (Budapest: Argumentum, 2005), 17-18.

93 Julier Ferenc, 'Ellenforradalmi lélekkel a Vörös Hadsereg élén 3', Hadtudomány, 31 (1993), 105.

94 See for example Pál Prónay: Béla Bodó, Pál Prónay: Paramilitary Violence and Anti-Semitism in Hungary, 1919-1921, (Pittsburgh: Center for Russian and East European Studies, 2011); and on the officer corps: Sándor Szakály, 'The Officer Corps of the Hungarian Red Army'.

Cite this article: Révész T (2022). A National Army Under the Red Banner? The Mobilisation of the Hungarian Red Army in 1919. Contemporary European History 31, 71-84. https://doi.org/10.1017/S0960777321000187 